\title{
NALAR KEISLAMAN URANG BANJAR
}

\author{
Muhammad Iqbal Noor *
}

\begin{abstract}
Tulisan ini membicarakan tentang perkembangan nalar keislaman urang Banjar dengan menggunakan pendekatan sejarah dan filsafat. Diawali dengan pengenalan terhadap nalar keislaman dan urang Banjar sebagai obyek dan subyek pembahasan. Kemudian dilanjutkan dengan mengungkapkan perkembangan nalar keagamaan dan nalar keislaman urang Banjar secara historis dan filosofis. Dalam tulisan ini diungkapkan babwa nalar keagamaan pra-Islam yang bersifat mitis berkembang menjadi nalar keislaman mistik, lalu tumbuh dan berkembang menjadi nalar keislaman formal, dan akbirnya tumbuh nalar keislaman ilmiah yang sesunggubnya belum begitu berkembang. Perkembangan satu nalar kenalar lainnya tidak bersifat linear dalam arti saling menggantikan tapi lebih bersifat overlapping, di mana ketika muncul nalar baru sesunggubnya nalar lama masib hidup.
\end{abstract}

Kata Kunci: nalar keislaman, urang Banjar, mistik, formal, ilmiah.

\section{Pendahuluan}

Dalam sosiologi pengetahuan diyakini bahwa ada inter-relasi antara masyarakat dan pengetahuan. Ruang sejarah menjadi tuan rumah bagi dialektika masyarakat dan pengetahuan itu. Dialektika antara keduanya tidak akan pernah mati kecuali ruang sejarah sudah tiada. Dialektika yang terus terjadi itu akan selalu memunculkan perubahan-perubahan pada masyarakat dan pengetahuan sehingga selalu akan muncul masyarakat dan pengetahuan yang baru di ruang sejarah. Dengan lain perkataan, tidak ada masyarakat dan pengetahuan yang tetap, semuanya pasti akan berubah karena dalam sejarah tidak ada yang tidak berubah kecuali perubahan itu sendiri.

Urang Banjar dikenal sebagai masyarakat yang Islami. Itu terlihat misalnya dari maraknya kegiatan-kegiatan keberagamaan di masyarakat ini. Secara

\footnotetext{
*Penulis adalah dosen tetap Fakultas Tarbiyah IAIN Antasari Banjarmasin.
} 
arsitektur daerah Banjar juga dikenal sebagai daerah seribu langgar (musholla). Suatu keadaan yang menunjukkan bahwa nafas Islami sangat kental di daerah ini. Urang Banjar yang Islami itu tentu tidak terbentuk begitu saja seperti turun dari langit. Ada proses dialektika yang terus menerus antara budaya lokal dengan budaya baru, dialektika antara urang Banjar dan Islam sebagai sistem pengetahuan. Dalam tulisan ini akan diuraikan bagaimana proses dialektika antara keduannya itu memunculkan perubahan atau perkembangan nalar keislaman atau keagamaan, sebagai bagian dari pengetahuan, pada urang Banjar.

Untuk itu akan digunakan dua pendekatan, yaitu sejarah dan filsafat. Sejarah digunakan untuk melihat secara periodik perkembangan nalar keagamaan dan keislaman beserta unsur-unsur yang turut dan mempengaruhi di dalam perkembangan tersebut. Sedang filsafat akan digunakan untuk menganalisa secara ontologis, epistemologis dan aksiologis keislaman yang dibangun oleh nalar-nalar yang berkembang itu.

Pembahasan akan dimulai dari pengertian nalar keislaman dan urang Banjar sebagai obyek dan subyek pembahasan. Kemudian dilanjutkan dengan perkembangan nalar keagamaan pra-Islam, dan akhirnya ditutup dengan pembahasan mengenai perkembangan nalar keislaman urang Banjar yang dibagi kepada tiga periode: mistik, formal, dan ilmiah.

\section{Apa itu Nalar Keislaman?}

Kajian tentang nalar akhir-akhir ini menjadi salah satu tren dalam studi Islam. Arkoun dalam bukunya Târîkhiyyah al-Fiker al-'Arabî al-Islâmî̀ mengkaji nalar keislaman dengan pendekatan dekonstruksi. Dengan itu Arkoun mencoba mengembalikan produk-produk pemikiran, baik yang furûiyyah maupun ushûliyyah, kepada kesejarahannya dan melakukan pembongkaran dan penggalian lapisan-lapisannya untuk membuka mekanisme penghalangan, pengisolasian, figuration yang diberlakukan. Muhammad 'Ẩbid al-Jâbirî, intelektual asal Maroko, melalui proyek kritik nalar Arab-nya menerbitkan Takwin al-'Aql al-'Arabì dan Bunyah al-'Aql al-'Arabî.' Dalam proyek itu al-Jâbiri menggunakan dua pendekatan yang saling berjalin kelindan dalam kerangka strukturalisme: pertama, pendekatan epistemologis, yakni untuk melihat kaidah

${ }^{1}$ Muhammad Arkoun, Târîkbiyyah al-Fiker al-'Arabî al-Islâmî, terj. Hasim Salih, (Libanon: Markaz al-Inma' al-Qoumî, 1986).

${ }^{2}$ Muhammad 'Âbid al-Jâbirî, Takwîn al-'Aql al-'Arabî, (Beirut: Markaz Dirâsât al-Wihhdah al-'Arabiyyah, 1989).

${ }^{3}$ Muhammad 'Âbid al-Jâbirî, Bunyah al-'Aql al-'Arabî, (Beirut: Markaz Dirâsât al-Wihhdah al-'Arabiyyah, 1990). 
berpikir yang membentuk ilmu-ilmu keagamaan selama ini; kedua, pendekatan ideologis, yakni dalam melihat kondisi sosial dan politik yang mempengaruhi arah pemikiran setiap tokoh pada masa dan tempat dia berada. Selanjutnya 'Alî Harb, dengan mengusung proyek "Kritik Teks (Naqd al-Nashsh) ${ }^{4}$ mengritik dua intelektual sebelumnya dan juga kritikus nalar lainnya sebagai "pemuja nalar". Menurutnya, rekonstruksi nalar yang dilakukan itu menjadi omong kosong tanpa melakukan proses dekonstruksi terhadap "teks" yang telah mengadakan nalar-nalar. Sebab teks-teks itulah yang menciptakan nalar-nalar. Teks, bagi 'Alî Harb, tidak hanya terbatas pada kitab suci al-Qur'an, tapi keseluruhan aktivitas yang dapat dipahami oleh manusia. Meskipun tidak muncul dalam kutipankutipan, namun pemikiran-pemikiran tokoh-tokoh di atas memberikan landasan bagi tulisan ini.

Sebelum melangkah lebih jauh, perlu diklarifikasi terlebih dahulu apa yang dimaksud dengan nalar di sini. Istilah nalar dapat dibedakan menjadi dua: nalar obyektif dan nalar subyektif. ${ }^{5}$ Nalar obyektif adalah nalar yang digunakan setiap orang dalam berpikir yang terlepas dari latar belakang eksistensialnya. Dengan nalar itu, contohnya manusia belajar membaca dan menghitung. Dengan nalar itu pula manusia dapat memahami bahwa air yang dipanaskan hingga $100^{\circ} \mathrm{C}$ akan mendidih. Semua itu tidak ditentukan oleh latar belakang eksistensial seorang manusia. Baik dia orang Kelua, Barabai, Negara, Jawa, Madura, Bugis, bahkan Eropa tidak akan berbeda. Sedangkan nalar subyektif adalah nalar yang terikat dan terbentuk oleh latar belakang eksistensial seorang anak manusia yang menyejarah. Nalar dalam pengertian inilah yang sesungguhnya dibicarakan oleh tokoh-tokoh di atas. Dengan nalar ini, contohnya orang menilai model pakaian yang bagus dan tidak bagus. Dengan nalar ini pula orang menilai apakah seseorang itu mulia atau tidak mulia, cantik atau tidak cantik, adil atau tidak adil, bahkan agamis atau tidak agamis. Nalar inilah yang melahirkan banyak aliran, mulai aliran pemikiran hingga aliran musik.

Istilah nalar yang dibahas dalam tulisan ini adalah dalam pengertian nalar subyektif sebagaimana telah di bahas oleh tokoh-tokoh sebelumnya. Pengertian

4‘Alî Harb, Kritik Nalar Al-Qur'an, terj. M. Faisal Fatowi, (Yogyakarta: LKIS, 2003).

${ }^{5}$ Bandingkan dengan konsep Lalande, sebagaimana dikutip al-Jabiri, tentang al-'aql almukawwan dan al-'aql al-mukawnin. Lihat Muhammad 'Âbid al-Jâbirî, Takwîn al-'Aql al-'Arabî, h. 15. 
nalar seperti ini sepadan dengan istilah episteme $e^{6}$ Michel Foucault, paradigma ${ }^{7}$ Thomas Khun, dan dalam batas-batas tertentu juga dengan istilah prasangka ${ }^{8}$ Gadamer. Secara sederhana nalar dalam pengertian ini dapat dikatakan sebagai sekumpulan kaidah yang menjadi pola pandang hidup dan landasan untuk menentukan nilai dan kebenaran bagi seseorang atau kelompok sebagai hasil dialektika dengan lingkungan eksistensial. ${ }^{9}$

Sedang keislaman berasal kata Islam yang ditambah imbuhan ke-an. Penambahan imbuhan ini biasa digunakan untuk menunjukkan suatu manifestasi dari kata asalnya pada sesuatu. Misal dalam dongeng si Kancil dan Buaya, Kancil dikatakan binatang yang pintar. Kepintaran si Kancil termanifestasi dalam kemampuannya mengelabui si Buaya hingga ia mampu menyelamatkan diri dari cengkraman Buaya. Kepintaran mungkin saja termanifestasi dalam berbagai bentuk, tidak hanya terbatas seperti dalam kasus si Kancil. Begitu juga dengan kata keislaman dalam tulisan ini, ia merupakan manifestasi Islam secara nyata pada seseorang atau kelompok tertentu.

Keislaman — sebagai manifestasi Islam- bisa tampil dalam rupa dan wujud yang berbeda pada tiap orang atau kelompok. Keislaman yang berbeda itu sesungguhnya merupakan konsekuensi logis dari perbedaan nalar yang membangunnya. Nalar yang membangun keislaman inilah yang dimaksud dengan nalar keislaman dalam tulisan ini. Singkatnya, nalar keislaman adalah kaidah-kaidah yang menjadi pola pandang hidup dan landasan untuk menentukan nilai keislaman atau manifestasi Islam pada seseorang atau kelompok tertentu.

${ }^{6}$ Episteme diartikan sebagai pandangan hidup (world-view) tertentu dalam suatu periode yang tidak disadari oleh orang-orang pada periode tersebut, namun setiap pemikiran dan pandangan pada masa itu tidak dapat keluar dari berbagai norma dan postulat dalam pandangan hidup tersebut. Lihat Michel Foucault, The Archeology of Knowledge, terj. A. M. Sheridan Smith, (London: Tavistock Publications, 1974), h. 191.

${ }^{7}$ Paradigma adalah kerangka referensi yang mendasari sejumlah teori maupun praktikpraktik ilmiah para ilmuwan. Lihat Thomas S. Khun, The Structure of Scientific Revolution (Herndon: The University of Chicago Press, 1970), h. 11-18.

${ }^{8}$ Prasangka adalah cakrawala pemahaman yang melandasi pandangan seseorang tentang sesuatu. Lihat Josef Bleicher, Contemporary Hermeneutics: Hermeneutics as Method, Philosophy, and Critique, London: Routledge \& Kegan Paul, 1980, h. 108

${ }^{9}$ Bandingkan dengan pengertian nalar yang diungkapkan al-Jabiri. Lihat Muhammad 'Âbid al-Jâbirî, Takwîn al-'Aql al-'Arabî, h. 15. 


\section{Urang Banjar}

Tidak ada sumber sejarah yang secara jelas mengatakan kapan istilah urang banjar muncul. Namun semua istilah Banjar tidak mungkin dilepaskan dari keberadaan kerajaan Banjar. Begitupun urang Banjar ada karena adanya kerajaan Banjar. Kerajaan Banjar adalah kerajaan terakhir yang pernah ada di daerah Kalimantan Selatan, yakni sekitar abad ke-16. Keberadaan kerajaan Banjar sendiri tidak lepas dari dampak perebutan tahta di Negara Daha, yaitu antara Pangeran Temanggung dengan Pangeran Samudera. Dalam kemelut itu Pangeran Samudera mengasingkan diri di hilir sungai Barito dan dalam perlindungan kelompok Melayu yang dipimpin oleh Patih Masih. Daerah itu oleh orang Dayak Ngaju disebut sebagai Banjar Oloh Masih (kampung orang Melayu) yang sekarang dikenal dengan Banjarmasin. ${ }^{10}$

Sebuah spekulasi sejarah mengatakan bahwa urang Banjar dulunya adalah bangsa atau warganegara kerajaan Banjar yang berdaulat. Namun ketika kerajaan Banjar yang berdaulat itu dijajah dan menjadi bagian dari teritori Negeri penjajah maka bangsa Banjar lenyap, dan turun derajatnya menjadi bangsa jajahan dan kemudian dikenal sebagai urang Banjar atau orang Banjar. ${ }^{11}$ Kalau kita menerima spekulasi itu maka dapat dipahami bahwa urang Banjar pada awalnya bukan merupakan etnik atau suku tapi lebih sebagai komunitas atau group.

Dari hasil penelitian yang dilakukan oleh Badan Penelitian dan Pengembangan Daerah Propinsi Kalimantan Selatan, urang Banjar itu setidaktidaknya terdiri dari etnik Melayu sebagai etnik dominan, kemudian ditambah unsur Bukit, Ngaju dan Maanyan. Tentu saja ada dialektika kultural antar unsur yang membentuk kebudayaan urang Banjar. Dialektika kultural itu dapat dilihat dari bahasa Banjar yang digunakan urang Banjar sebagai bahasa percakapan sehari-hari. Sebagian besar kosa kata bahasa Banjar diambil dari kosa kata melayu dan sebagian kecil dijumpai sejumlah kata yang mirip dengan bahasa Ngaju, Maanyan dan Deyah. Kata "Banjarmasin" misalnya, kata ini berasal dari kata "banjarmasib" yang terdiri dari kata banjar dan masib. Banjar berasal dari bahasa Melayu yang berarti kampung dan masih berasal dari bahasa Ngaju yang

${ }^{10} \mathrm{M}$. Suriansyah Ideham dkk (ed.), Urang Banjar dan Kebudayaannya,cet. ke-2 (Banjarmasin: Badan Penelitian dan Pengembangan Daerah Propinsi Kalimantan Selatan, 2007), h.19.

${ }^{11} \mathrm{M}$. Suriansyah Ideham dkk (ed.), Sejarah Banjar, cet. ke-3 (Banjarmasin: Badan Penelitian dan Pengembangan Daerah Propinsi Kalimantan Selatan, 2007), h. 106 
merupakan sebutan terhadap orang Melayu. Jadi "banjarmasib" adalah sebutan bagi perkampungan orang Melayu dalam bahasa Ngaju. ${ }^{12}$

Meskipun paparan di atas menunjukkan bahwa urang Banjar muncul seiring munculnya kerajaan Banjar, namun eksistensi masyarakat yang kemudian disebut sebagai urang Banjar itu sudah ada jauh sebelum adanya kerajaan Banjar. Dalam pengertian ini kita tidak lagi mengatakan urang Banjar sebagai afiliasi kepada kerajaan Banjar saja, tapi juga kerajaan-kerajaan sebelumnya yang merupakan bagian yang tak terpisahkan dari keberadaan kerajaan Banjar. Dalam pengertian lain dapat dikatakan urang Banjar atau masyarakat Banjar telah terbentuk sebagai kelompok sosial budaya sebelum kerajaan Banjar itu sendiri muncul.

Jauh sebelum kerajaan Banjar muncul sudah ada sebuah kerajaan yang bernama Tanjungpura atau Tanjungpuri di daerah Kalimantan Selatan. Kerajaan ini dibentuk oleh imigran Melayu. ${ }^{13}$ Kenyataan ini dipertegas oleh Alfani Daud yang mengatakan kemungkinan asal-usul urang Banjar adalah pecahan etnik Melayu yang dalam ribuan tahun silam bermigrasi dari Sumatera dan sekitarnya ke daerah ini. Hal ini dapat dilihat dari kesamaan yang besar antara bahasa Banjar dan bahasa Melayu. ${ }^{14}$ Ada beberapa spekulasi mengenai lokasi kerajaan ini, namun beberapa sumber mengatakan ia berada di Tanjung, ibu kota Kabupaten Tabalong sekarang. ${ }^{15}$

Beberapa waktu setelah itu sekitar abad ke-13, muncul sebuah kerajaan bernama Negara Dipa di Hujungtanah, tempat pertemuan sungai Amandit dan sungai Negara. ${ }^{16}$ Kerajaan ini merupakan kerajaan migrasi dari Jawa Timur sebagai akibat peperangan antara Ken Arok dan Kertajaya yang dikenal dengan Perang Ganter. Dalam perkembangan selajutnya Negara Dipa bertransformasi menjadi Negara Daha dan berlokasi di sekitar Negara sekarang. ${ }^{17}$

Selanjutnya sebagaimana disinggung sebelumnya terjadi persengketaan kekuasaan antara Temanggung dengan Pangeran Samudera yang kemudian memunculkan kerajaan Banjar dan secara tidak langsung juga memunculkan urang Banjar. Demikianlah sekilas pembahasan tentang urang Banjar.

${ }^{12}$ Ibid, h. 106-107

${ }^{13}$ Ibid, h. 105

${ }^{14}$ Alfani Daud, Islam dan Masyarakat Banjar: Deskripsi dan Analisa Kebudayaan Banjar (Jakarta: Rajawali Press, 1997)

${ }^{15}$ Lihat M, Suriansyah Ideham dkk (ed.), Sejarah Banjar, h. 105-106

${ }^{16}$ M. Suriansyah Ideham dkk (ed.), Urang Banjar dan Kebudayaannya,h. 18

${ }^{17}$ Lihat M, Suriansyah Ideham dkk (ed.), Sejarah Banjar, h. 106 


\section{Potret Nalar Keagamaan Pra-Islam Urang Banjar}

Secara umum kepercayaan awal yang tumbuh di Kalimantan Selatan adalah animisme dan dinamisme sebagaimana ini juga terjadi di hampir seluruh daerah Nusantara. Kedua kepercayaan ini meyakini adanya kekuatan-kekuatan supranatural (keramat). Kekuatan-kekuatan itu pada animisme dan dinamisme termanifestasi dalam apa yang disebut sebagai alam roh. Kepercayaan akan adanya kekuatan-kekuatan keramat dalam kenyataan pengalaman ini disebut Berger dan Luckmann sebagai mitos. ${ }^{18}$ Oleh karenanya, nalar keagamaan yang terbangun dalam paham-paham awal ini adalah nalar mitis, yakni nalar yang dibangun dari mitos atau keyakinan akan kekuatan supranatural tertentu.

Nalar mitis keagamaan itu terlihat dari kepercayaan adanya roh-roh jahat bergentayangan yang dapat mengganggu kehidupan manusia, roh-roh tersebut bersemayam di tempat-tempat tertentu seperti batu besar, pohon besar atau tempat khusus lainnya. Agar roh-roh itu tidak mengganggu, bahkan sebaliknya dapat memberikan kesejahteraan, maka perlu dihormati dengan memberikan roh-roh tersebut sesaji dalam bentuk makanan dan minuman pada waktuwaktu tertentu sebagai bentuk tolak bala. Selain itu, tolak bala juga bisa dilakukan dengan menggunakan lambang-lambang tertentu seperti tanda + yang disebut dengan cacak burung. ${ }^{19}$

Kepercayaan seperti itu masih berkembang di masyarakat Banjar. Pada upacara daur hidup, tradisi tolak bala tercermin pada sesaji yang disebut piduduk pada setiap kegiatan batapung tawar, mandi-mandi pengantin, mandi-mandi kehamilan, baayun mulud dan lain-lain. Contoh lain, simbol cacak burung (+) dioleskan para pembuat tape pada tempat memproses makanan tersebur, dengan harapan tidak diganggu dan hasilnya memuaskan. Simbol ini juga digunakan untuk pengobatan anak kecil yang sakit panas (Banjar:kapidaraan), yaitu dengan mengoleskan antara kedua alis dengan bahan kunyit dicampur kapur sirih. ${ }^{20}$

Nalar mitis keagamaan pra-Islam juga terlihat pada kepercayaan akan adanya roh yang bermukim pada suatu benda. Karenanya, sikap yang terbangun kemudian adalah mengeramatkan benda-benda tertentu. Mengeramatkan benda juga masih terlihat dalam masyarakat Banjar, yaitu

${ }^{18}$ Peter L. Berger dan Thomas Luckmann, Tafsir Sosial atas Kenyataan: Risalab tentang Sosiologi Pengetahuan (Jakarta: LP3ES, 1990), h. 6

${ }^{19}$ M. Suriansyah Ideham dkk (ed.), Urang Banjar dan Kebudayaannya,h. 48

${ }^{20} \mathrm{Ibid}$, h. 50-51. 
kepercayaan akan adanya tuah dari benda pusaka seperti keris, tombak, parang, cemeti dan lainnya yang sering disebut sebagai wasi tuha. ${ }^{21}$

Kalau kita memotret nalar keagamaan animisme dan dinamisme di atas secara filosofis, maka dapat dikatakan bahwa keagamaan secara ontologi adalah kenyataan atau kegiatan obyektif yang bersifat mitis. Secara epistemologi pengetahuan keagamaan lebih bersifat mitologisme karena dibangun dari mitologi-mitologi yang berkembang di masyarakat. Sedang secara aksiologi atau fungsi keagamaan sesungguhnya lebih bersifat duniawi yakni untuk keselamatan hidup di dunia.

Dalam perkembangan selanjutnya, animisme dan dinamisme sebagai budaya lokal bertemu dengan Budhisme dan Hinduisme yang dibawa oleh para imigran. Budhisme dan Hinduisme semakin kokoh seiring berdirinya kerajaan Tanjungpura(i) dan Negara Dipa. Tidak ada sumber tertulis yang menguraikan perihal keagamaan yang berkembang pada masa itu, namun adanya peninggalan Candi Agung dan Candi Laras memberikan bukti akan adanya suatu keagamaan karena candi biasa digunakan sebagai tempat ibadah.

Tidak adanya sumber tertulis mengenai ajaran Budhisme dan Hinduisme di Kalimantan Selatan memang menyulitkan kita untuk memotret bagaimana nalar keagamaan yang berkembang. Namun dari berbagai ceritera rakyat yang berkembang masih nampak mitos menguasai kesadaran keagamaan masa itu. Mitos yang paling populer adalah tentang Putri Junjung Buib. Dalam mitos itu diceritakan bahwa Mpu Jatmika sebelum wafat berwasiat kepada kedua anaknya Lambung Mangkurat dan Mpu Mandastana agar jangan berniat untuk menjadi raja, sebab mereka bukanlah keturunan raja. Mpu Jatmika sendiri hanya menganggap dirinya sebagai raja sementara, sebab yang dianggap sebagai raja pertama adalah patung dirinya yang terbuat dari kayu cendana. Patung inilah yang disembah oleh rakyat sebagai raja. Konon itu dilakukan untuk menghindari kutukan karena Mpu Jatmika tak pantas menjadi raja karena bukan keturunan raja. Karena itu ia menyuruh Lambung Mangkurat pergi bertapa untuk mencari raja yang sah. Pasca wafat ayahnya, Lambung Mangkurat melakukan tapa brata (balampah) di sebuah sungai. Ketika sedang bertapa, tibab-tiba di pusaran air keluar buih yang bersinar, lalu muncul seorang puteri. Puteri itu kemudian diberinama Putri Junjung Buih (puteri dari buih yang dimuliakan) dan diangkat menjadi ratu di Negara Dipa. Begitupun juga suami Puteri Junjung Buih, Pangeran Suryanata diperoleh Lambung Mangkurat

${ }^{21}$ Ibid. Lihat juga Ahmad Basuni, Nur Islam di Kalimantan Selatan (Sejarah Masuknya Islam di Kalimantan) (Surabaya: PT. Bina Ilmu, 1986), h. 48. 
melalui tapa brata. ${ }^{22}$ Dilihat dari cerita itu tampak ada pergeseran nilai-nilai keramat dari roh-roh yang bersifat metafisik kepada pribadi-pribadi (yang dianggap) suci seperti Putri Junjung Buih dan Pangeran Suryanata. Walaupun dalam batas-batas tertentu pola animisme dan dinamisme tidak sepenuhnya sirna. Itu terlihat dari keberadaan patung Mpu Jatmika yang disembah.

Personifikasi kekeramatan pada pribadi dalam cerita di atas menunjukkan adanya struktur nalar Hindu. Dalam Upanisad ada ajaran tentang hubungan antara Atman dan Brabman, mikrokosmos dan makrokosmos. Tapa brata atau yoga dalam ajaran Hindu adalah jalan penghubung antara keduanya. Putri Junjung Buih dan Pangeran Suryanata sebagai hasil tapa brata merupakan lambang kesatuan antara atman dan brahman, mikrokosmos dan makrokosmos karena keduanya merupakan perpanjangan tangan —untuk tidak mengatakan inkarnasi- Tuhan untuk menata dunia fana.

Sampai di sini kita melihat bahwa nalar keagamaan masyarakat Banjar pada masa Hinduisme berkembang dari nalar keagamaan mitis ke arah nalar keagamaan yang lebih mistik karena meyakini adanya kesatuan fundamental yang bersifat ilahiah. Secara ontologi ada pergeseran keagamaan dari kegiatan obyektif yang bersifat mitis kepada kegiatan batin yang bersifat mitis. Epistemologi yang terbangun juga berubah dari mitologisme kepada intuisimistisme yang didasarkan pada kesatuan fundamental. Sedang secara aksiologi keagamaan masa Hinduisme masih tidak bergeser dari keagamaan animisme dan dinamisme, yaitu untuk keselamatan atau kesejahteraan dunia. Demikianlah sekilas perkembangan nalar keagamaan urang Banjar pra-Islam.

SKEMA FILOSOFIS NALAR KEAGAMAAN PRA-ISLAM

\begin{tabular}{|l|c|c|}
\hline & $\begin{array}{c}\text { Animisme dan } \\
\text { Dinamisme }\end{array}$ & Hinduisme \\
\hline Ontologi & Realisme-mitis & Idealisme-mitis \\
\hline Epistemologi & Mitologisme & Intuisi-mistisisme \\
\hline Aksiologi & Keselamatan dunia & Keselamatan dunia \\
\hline
\end{tabular}

${ }^{22}$ M. Suriansyah Ideham dkk (ed.), Sejarah Banjar, h. 54-56 


\section{Perkembangan Nalar Keislaman Urang Banjar}

Sebelum menguraikan pembahasan ini, perlu penulis sampaikan sebelumnya bahwa pembahasan ini dipengaruhi oleh beberapa pemikiran, yakni Hukum Tiga Tahap (teologis, metafisik, dan posotif) yang diungkapkan oleh Auguste Comte dan periodisasi sejarah kesadaran keagamaan (mitos, ideologi, dan ilmu) yang diungkapkan Kuntowidjoyo. Oleh karenanya, kita juga membagi periode nalar keislaman urang Banjar menjadi tiga: periode mistik, formal, dan ilmiah. Namun perlu diungkapkan sebelumnya bahwa perkembangan nalar keislaman urang Banjar tidak merupakan evolusi linear, dalam arti yang baru menggantikan yang lama, tapi lebih bersifat overlapping. Pada periode formal misalnya, sebenarnya periode mistik terus berjalan. Demikian juga pada periode ilmiah, sebenarnya periode mistik dan formal juga terus berjalan. Bahkan lebih dari itu, pada ketiga periode nalar keislaman nalar keagamaan sebelumnya yang lebih bersifat mitis juga masih terus berjalan sebagaimana diungkapkan sebelumnya.

\section{Periode Mistik}

Ada dua pertemuan ilmiah mengenai sejarah perkembangan Islam di Kalimantan Selatan. Yang pertama adalah pra Seminar Sejarah Kalimantan Selatan yang berlangsung 23-25 September 1973 dan yang kedua adalah Seminar Sejarah Kalimantan yang berlangsung tanggal 8-10 April 1976. Dari kedua pertemuan itu disimpulkan berdirinya kerajaan Islam Banjar tidak identik dengan masuknya agama Islam ke Kalimantan Selatan. Dengan kata lain, Islam masuk ke Kalimantan Selatan sudah terjadi jauh sebelum berdirinya Kerajaan Islam Banjar. ${ }^{23}$

Perkembangan awal Islam itu tentu saja tidak dapat dilepaskan begitu saja dari corak keberagamaan mistik yang sudah menjadi pandangan hidup urang Banjar sebelumnya sebagai warisan dari budaya Hindu. Apalagi jika melihat tren nalar keislaman yang lebih bersifat mistik di awal perkembangannya di seluruh Nusantara, hal ini semakin memperkuat bahwa periode awal perkembangan Islam di Banjar semangat yang ada adalah mistifikasi Islam, yaitu memanifestasikan keislaman mistik yang meyakini adanya kesatuan fundamental secara ontologi. Keadaan ini sesungguhnya memberikan keuntungan tersendiri bagi proses Islamisasi, karena sifatnya yang lebih akomodatif terhadap budaya lokal. Di mana-mana tidak mungkin diterima suatu budaya baru secara baik-baik apabila budaya itu bertolak 
belakang sama sekali dengan budaya lokal. Dugaan ini diperkuat dengan adanya tokoh sufi berhaluan wahdatul wijud yang bernama Syekh Ahmad Syamsuddin al-Banjari (lahir 1618 M) yang menulis tentang Asal Kejadian Nur Mubammad. Risalah ini kemudian dihadiahkan kepada Ratu Aceh Sulthanah Seri Ratu Tajul Alam Safiatuddin Johan Berdaulat (1641-1675 M). ${ }^{24}$

Sebelum melangkah lebih jauh dalam pembahasan perkembangan nalar keislaman periode mistik, perlu diuraikan terlebih dahulu di sini segala hal yang berkaitan dengan istilah wabdatul wrijud. Istilah ini biasanya dihubungkan dengan Ibn 'Arabi, karena tokoh ini dianggap pendirinya. Namun, penyelidikan tentang sejarah istilah wabdatul wujud belakangan ini ternyata membatalkan anggapan tersebut. Istilah wabdatul wujud tidak diciptakan oleh sufi terkenal asal Mursia ini. Ia sendiri tidak pernah menggunakan istilah ini. Dalam karya-karyanya, istilah ini tidak pernah ditemukan. Penelitian awal tentang sejarah istilah wabdatul wujud yang dilakukan William C. Chittick menunjukkan bahwa Shadr al-Dîn al-Qûnawî merupakan orang pertama yang menggunakan istilah ini. Akan tetapi, ia tidak menggunakannya sebagai suatu istilah teknis yang independen. Istilah ini muncul secara wajar dalam pembicaraannya tentang hubungan antara wujud Tuhan dan keesaan-Nya. ${ }^{25}$

Sebenarnya istilah wabdatul wrjud tidak hanya merujuk pada satu pengertian. Ada tujuh pengertian tentang itu sebagaimana diungkapkan oleh Chittick: 1) wabdatul wujud menunjukkan suatu aliran pemikiran yang kembali kepada Ibn 'Arabi dan membuat pernyataan tertentu tentang sifat hubungan antara Tuhan dan alam; 2) merepresentasikan sebuah pernyataan tentang wujud atau realitas itu sendiri, tanpa suatu implikasi bahwa sebuah keseluruhan sistem pemikiran mendasarinya sebagaimana yang dilakukan oleh al-Qunâwî dan Farghani; 3) merepresentasikan sifat makhluk ciptaan. Dalam konteks ini, keserbaragaman tidak mesti dipahami memiliki satu realitas tertentu. Ini sebagaimana Ibn Sabi'in dan Nasafi menggunakannya; 4) sinonim dengan inkarnasionisme dan unifikasionisme, yakni tesis bahwa Tuhan dan alam adalah identik. Ini sebagaimana dipahami oleh Ibn Taimiyyah; 5) diartikulasikan dalam istilah wabdatusy syubud, sebagai usaha untuk menjaga kelainan Tuhan yang transenden dan mutlak seperti yang digunakan Ahamad Sirhindi; 6) dibedakan

${ }^{24}$ M. Suriansyah Ideham dkk (ed.), Urang Banjar dan Kebudayaannya,h.55

${ }^{25}$ William C. Chittick, "Rumi dan Wablah Al-Wujûd," dalam Kidung Rumi; Puisi dan Mistisisme Dalam Islam, ed. Amin Banani dkk, terj. Joko S. Kahhar, (Surabaya: Risalah Gusti, 2001), h. 101-112 dan Kautsar Azhari Noer, Ibn al'Arabî; Wabldah al-Wujûd dalam Perdebatan, (Jakarta: Paramadina, 1995), h. 34-36. 
secara normatif antara wabdatul wujud dan wabdatusy syubud. Yang pertama dipahami sebagai "monisme eksistensial yang statis" dan yang kedua dipahami sebagai "monisme testimonal yang dinamis". Ini misalnya digunakan oleh Massignon, dan yang terakhir; 7) dipahami sebagai sinonim yang tepat untuk tauhid secara ideal. ${ }^{26}$ Beberapa pengertian tersebut setidaknya dapat menjelaskan secara lebih komprehensif apa yang dimaksud dengan konsep wabdatul wujud di sini.

Kembali kepada pembahasan nalar keislaman periode mistik. Pengaruh tasawuf berhaluan wahdatul wijud yang terlihat pada tokoh Syekh Ahmad Syamsuddin al-Banjari selanjutnya dalam kurun abad ke-17 dan 18 juga terefleksikan pada tiga tokoh lainnya, yaitu Syekh Muhammad Nafis Bin Idris al-Banjari ${ }^{27}$, Syekh Abdul Hamid Abulung ${ }^{28}$, dan Datu Sanggul ${ }^{29}$. Hal ini semakin mempertegas bahwa perkembangan Islam di Banjar abad ke-17 sampai pertengahan abad ke-18 sangat dipengaruhi tasawuf yang bersifat mistik. $^{30}$

Dalam nalar mistik dipahami bahwa realitas yang sejati hanya Tuhan, maka makna segala sesuatu pada akhirnya adalah Tuhan itu sendiri. Yang lain tidak lebih dari sekedar realitas metaforis, tanda bagi Realitas Sejati. Eksistensi sejatinya hanyalah milik Sang Wujud, selainnya tidak lebih dari sebuah noneksistensi. Hal ini secara gamblang terlihat dalam ungkapan kontroversial Abdul hamid Abulung: "tiada yang manjud melainkan hanyalah Dia, tiada aku melainkan Dia, Dialah Aku, dan aku adalah Dia". Dalam tingkat yang berbeda hal ini juga tergambar dalam konsep fana Datu Sanggul dalam Kitab Barencong:

${ }^{26}$ William C. Chittick, ibid, h. 99-130

${ }^{27}$ Mengenai Syekh Muhammad Nafis Bin Idris al-Banjari, dalam ensiklopedi Islam dikatakan bahwa karyanya ad-Durrun Nafis yang ditulis sekitar tahun $1782 \mathrm{M}$ mengandung ajaran ajaran tasawuf sunni yang bercitarasa wahdatul wujud. Dengan lain perkataan, tokoh ini berusaha memperluas konsep wabdatul wujud yang diambil dari Ibnu Arabi dan para pengikutnya seperti Abdul Karim al-Jilli, Abdul Ghani al-Nablusi dan Abdullah bin Iberahim Hirghani. Lihat M, Suriansyah Ideham dkk (ed.), Sejarah Banjar, h. 189

${ }^{28}$ Ajaran wabdatul wujud Syekh Abdul Hamid Abulung sangat populer melalui ungkapannya: "tiada yang maujud melainkan hanyalah Dia, tiada aku melainkan Dia, Dialah Aku, dan aku adalah Dia". Lihat ibid, h. 190 dan M. Suriansyah Ideham dkk (ed.), Urang Banjar dan Kebudayaannya,h. 58.

${ }^{29}$ Konsep wabdatul wujud Datu Sanggul dapat terlihat dan terungkap secara halus dalam konsep fana-nya. Lihat Bayani Dahlan dkk, Studi Naskah Kitab Barencong Datu Sanggul (Banjarmasin: Pusat Penelitian IAIN Antasari Banjarmasin, 2007), h. 132-135.

${ }^{30} \mathrm{M}$. Suriansyah Ideham dkk (ed.), Urang Banjar dan Kebudayaannya,h.55 
Karena di dalam wujud sesuatu itu keadaan WUJUD ALLAH, tetapi pada syara tidak begitu. Adapun pada hakikat semuanya itu adalah isyarat Esa-Nya, karena pandang kita jangan menjadi majaz, hendaklah haqiqatnya bahwa sekalian itu adalah keadaan WUJUD ALLAH, karena sekalian alam ini tiada berwujud pada haqiqat melainkan keadaan WUJUD ALLAH dan ZAT ALLAH jua....

Yakni haramlah wujud majaz pada wujud haqiqat, maka sempurnalah tilik kita pada semesta sekalian alam yaitu Esa.

Nalar mistik lebih mementingkan sisi batin dalam keislaman. Dengan kata lain, keislaman dalam nalar nalar mistik lebih dipahami dalam konteks idealisme yang bersandar pada idea yang hadir dalam jiwa tidak dalam kenyataan. Jadi secara ontologi keislaman adalah kenyataan batin, yakni kesadaran bahwa yang ada hanyalah Allah. Karenanya, dalam nalar mistik urang Banjar dikenal ajaran "shalat daim" atau "Ilmu Sabuku", yaitu ajaran shalat sebelum shalat atau sekali shalat untuk seumur hidup ${ }^{32}$ karena shalat dalam nalar mistik berada pada idea, artinya kesadaran akan Tuhan Yang Esa secara terus menerus bukan pada kenyataan sebagai aktivitas yang sudah diatur dan ditentukan.

Karena yang ada (wujud) dalam nalar mistik adalah idea atau yang bathin, maka pengetahuan yang benar dalam nalar ini adalah yang bersifat bathin pula. Lebih jauh, dalam nalar mistik dipahami bahwa pengetahuan hanya milik Allah. Karenanya, dalam Risalah Tasawnf karya Syekh Abdul Hamid Abulung dan Kitab Barencong karya Datu Sanggul secara tegas dikatakan bahwa "tidak ada yang mengenal Allah kecuali Allah" 33 . Dengan begitu secara epistemologi dalam nalar mistik pengetahuan sejati hanya didapat langsung dari Allah secara intuitif yang dalam terminologi tasawuf disebut sebagai kasyf.

Secara umum diketahui fungsi ajaran Islam adalah untuk menegakkan tauhid, dan keislaman sesungguhnya merupakan manifestasi pengesaan (tauhid). Begitu juga secara aksiologi nalar mistik memandang keislaman, namun tauhid yang ingin diwujudkan adalah tauhid dalam aksen kesatuan wujud. Jadi buah yang ingin dicapai dari keislaman nalar mistik sesungguhnya adalah kesatuan wujud yang dipahami sebagai puncak kenikmatan.

\footnotetext{
${ }^{31}$ Bayani Dahlan dkk, Studi Naskah Kitab Barencong Datu Sanggul, h. 134.

${ }^{32}$ Syafruddin dan Syahriansyah, Ajaran Tasawuf Syekh Hamid Abulung (Yogyakarta: Sumbangsih Press, 2007), h. 101-102.

${ }^{33}$ Ibid, h. 73 dan Bayani Dahlan dkk, Studi Naskab Kitab Barencong Datu Sanggul, h. 132.
} 


\section{Periode Formal}

Sejarah munculnya periode ini sesungguhnya sangat berkaitan dengan seorang tokoh besar asal Banjar, Syekh Muhammad Arsyad al-Banjari. Dengan demikian periode ini berarti dimulai masa hidup beliau terutama kedatangan Sang tokoh di tanah Banjar selepas menuntut ilmu di tanah Arab, yakni sekitar pertengahan abad ke-18 M. Spirit pada periode ini adalah formalisasi Islam, dalam arti mengejawantahkan Islam sesuai sumber formalnya yakni teks alQur'an dan hadis dalam kenyataan. Dalam penuturan berbeda formalisasi adalah suatu usaha memformalkan teks al-Qur'an dan hadis dalam kenyataan obyektif. Dalam khazanah pemikiran Islam pola seperti ini adalah pola golongan ablussunah waljama'ah yang mengklaim diri sebagai penganut keislaman yang dianut Nabi Muhammad saw dan sahabat-sahabat beliau yang termanifestasi dalam teks al-Qur'an dan Hadis. Syekh Muhammad Arsyad sebagai tokoh sentral dalam periode ini secara tegas juga menyatakan diri sebagai pengikut ablussunah waljama'ah sebagaimana dituturkan:

Karena itu berhati-hatilah wahai orang yang beriman dan wajiblah beri'tikad dengan i'tikad ablussunah waljama'ah karena ia adalah i'tikad Nabi, para sahabat, tabi'in dan tabi'it tabi'in bahwa ia adalah i'tikad yang benar sampai hari kiamat. Karena itu wajiblah menjauh dari i'tikad ahlul bid'ah yang tersesat... ${ }^{34}$

Dengan demikian, segala hal yang tidak sesuai dengan norma-norma keislaman yang termaktub dalam dua sumber formal tidak dapat diterima oleh aliran ini. Sebagai contoh perwujudan sikap ini adalah penentangan Syekh Muhammad Arsyad al-Banjari terhadap praktik upacara membuang pasilib dan manyanggar ${ }^{35}$ karena tidak sesuai dengan norma-norma sebagaimana disebut di atas. Ada tiga kemungkaran yang terdapat dalam kedua upacara itu. Pertama, mubadzir atau membuang-buang harta pada jalan yang diharamkan. Pelakunya adalah teman setan sebagaimana tertera dalam al-Qur'an surah al-Isra:27. Kedua, mengikuti setan dan memenuhi permintaanya yang bertentangan

${ }^{34}$ Syekh Muhammad Arsyad al-Banjari, "Tuhfatur Ragibin fi Bayani Haqiqati Imani alMu'minin wama Yufsidubu Min Riddatil Murtadin", dalam Asywadie Syukur, Pemikiran- Pemikiran Syekh Mubamad Arsyad Al Banjari dalam Bidang Taubid dan Tasawuf (ttp: tp, 2004), h. 31.

${ }^{35}$ Upacara pemberian sesajian yang diperuntukkan kepada arwah para leluhur dan kekuatan gaib lainnya untuk diminta pertolongan dukun agar dapat menyembuhkan penyakit, membuang sial, dan mengabulkan permintaan melalui mediasi dukun yang sedang trance (kerasukan), ketika sedang melakukan komunikasi dengan kekuatan supranatural. Urang Banjar dan Kebudayaannya, h. 62. 
dengan al-Qur'an surah al-Baqarah:208, an-Nisa:119, dan al-Fathir:6. Ketiga, megandung syirk dan bid'ah. ${ }^{36}$ Demikianlah, kedua upacara tersebut tidak dapat diterima karena tidak sesuai dengan norma-norma yang tertuang teks al-Qur'an dan penghapusan keduanya merupakan bentuk formalisasi nash al-Qur'an dan hadis.

Dalam periode formal ontologi keislaman yang mau dibangun adalah realisme, yakni realitas atau kenyataan obyektif yang sesuai dengan normanorma formal. Pernyataan itu semakin jelas apabila kita melihat fatwa sesat terhadap keislaman model Syekh Abdul Hamid Abulung yang bersifat mistik dan tidak sesuai dengan sumber formal Islam. Atas dasar fatwa ini Raja pada masa itu, Sultan Tahmidillah memerintahkan hukum mati atas penganut paham wabdatul wujud tersebut. ${ }^{37}$ Usaha untuk menyesuaikan realitas dengan normanorma formal semakin sukses saat Sultan Adam al-Wasik Billah yang memerintah di Kerajaan Banjar (1825-1857) yang diperkirakan pada masa mudanya pernah menjadi murid Syekh Muhammad Arsyad menetapkan suatu ketentuan hukum yang sampai sekarang dikenal sebagai "Undang Undang Sultan Adam" pada tanggal 15 Muharram $1251 \mathrm{H}(1835 \mathrm{M}) .{ }^{38}$

Pada periode ini, atas jasa besar Syekh Muhammad Arsyad Islam akhirnya berkembang sangat pesat di Banjar. Selain melalui tulisan pendidikan agama Islam juga dilakukan melalui lembaga pesantren. Pesantren pertama yang dibangun Syekh Muhammad Arsyad bertempat semula di bekas tanah hutan belukar di luar kota Martapura, di tepi sungai Martapura. Bekas tanah hutan belukar itu diberi keliling pagar dan hingga kini dinamakan Kampung Dalam Pagar. ${ }^{39}$ Di pesantren itu diajarkan membaca dan menulis huruf Arab, meningkat membaca al-Qur'an, dilanjutkan dengan pelajaran ibadah fiqh dan tauhid yang dimlakan karena belum ada kitab-kitabnya. Para santri harus menyalin dalam bukunya. Pada tingkat selanjutnya santri diajarkan ilmu-ilmu berkaitan dengan Bahasa Aran seperti ilmu sharf dan nabwu. ${ }^{40}$ Dari situ terlihat bahwa epistemologi yang dibangun dalam nalar formal bersifat tekstualnormatif dengan alat pemahaman utamanya adalah ilmu bahasa. Epistemologi seperti ini berkembang seiring berkembangnya pesantren di Kalimantan Selatan.

\footnotetext{
${ }^{36}$ Syekh Muhammad Arsyad al-Banjari, “Tuhfatur Ragibin..., h. 72-79.

${ }^{37}$ M. Suriansyah Ideham dkk (ed.), Sejarah Banjar, h. 190.

${ }^{38} \mathrm{Ibid}$, h. 203.

${ }^{39}$ Ahmad Basuni, Nur Islam di Kalimantan Selatan, h.52.

${ }^{40} \mathrm{Ibid}$.
} 
Sedang aksiologi keislaman dalam nalar formal sesungguhnya tidak berbeda dengan fungsi ajaran Islam secara ideal, yakni menegakkan tauhid. Tapi manifestasi tauhid dalam nalar ini adalah ketaatan pada norma. Artinya, seseorang dikatakan bertauhid apabila ia menjalankan segala yang diperintahkan dan menjauhi segala larangan yang semuanya itu dipahami secara tekstual-normatif.

\section{Periode Ilmiah}

Sebelum melangkah membicarakan periode ini secara empiris pada urang Banjar, perlu diungkapkan terlebih dahulu spirit yang dibangun dalam periode ini. Spirit periode ini adalah rasionalisasi keislaman, dalam arti mewujudkan keislaman yang bisa diterima secara fitrah-rasional, tidak secara dogmatis maupun mistik. Kalau berbicara konsep politik, ekonomi, pendidikan dan lainnya maka tidak hanya dalam wilayah domestik secara dogmatis yang hanya diterima kalangan umat Islam sendiri, tapi juga dalam wilayah universal secara rasional yang bisa diterima oleh semua umat. Singkatnya, dalam membicarakan konsep politik, ekonomi, pendidikan dan lainnya tidak hanya menggunakan dalil-dalil tekstual yang bersifat subyektif tapi juga dalil-dalil ilmiah yang bersifat obyektif sehingga dapat diterima secara universal.

Sulit untuk menyebutkan kapan periode ini dimulai. Kesulitan itu yang pertama, karena secara umum keislaman urang Banjar hingga saat ini masih bersifat formal. Karenanya tidak salah kalau orang mengatakan bahwa Syekh Muhammad Arsyad al-Banjari masih hidup sampai saat ini di masyarakat Banjar. Yang kedua karena memang periode ini masih samar-samar, antara tiada dan ada. Karenanya yang ketiga, harus jujur dikatakan bahwa kita belum melihat satu sosok urang Banjar yang definitif yang bisa diafiliasasikan secara tegas pada pembentukan nalar ilmiah.

Meskipun begitu sesungguhnya ada beberapa produk pemikiran cendikiawan kalangan kampus yang dapat sedikit mewakili periode atau cikal bakal periode ini. Diantaranya — sejauh pengetahuan penulis yang belum begitu lama menggeluti pemikiran para cendikiawan Banjar kontemporeradalah pemikiran Prof. Dr. H. Kamrani Buseri dan Dr. Mujiburrahman. Kamrani Buseri dengan konsep pendidikan Islam integratifnya yang mencoba menyatukan konsep hamba dan khalifah dalam bentuk penyatuan "ilmu agama" dan "ilmu umum". Konsep ini merupakan wacana baru di tengah derasnya ortodoksi ilmu agama yang bersifat dogmatis. Sedang Mujiburrahman

${ }^{41}$ Kamrani Buseri, Paradigma Pendidikan Islam. (Disampaikan pada Rapat Senat Terbuka dalam rangka pengukuhan Guru Besar IAIN Antasari Banjarmasin, 2005) 
melalui Mengindonesiakan Islam-nya berusaha mewujudkan obyektivasi nilai-nilai Islam di Indonesia. ${ }^{42}$ Belum banyak urang Banjar yang berusaha menampilkan "wajah Indonesia" di balik "jati diri Islam" seperti yang dilakukan Mujiburrhaman ini. Dua pemikiran di atas secara struktural dapat diafiliasikan kepada nalar ilmiah walaupun harus jujur dikatakan bahwa kedua tokoh tersebut sampai saat ini belum memperlihatkan pengaruh yang signifikan dalam pembentukan nalar ilmiah urang Banjar.

Secara sosial periode ini sesungguhnya sudah tampak seiring terjadinya dialektika antara ilmu-ilmu agama klasik dan ilmu-ilmu modern dalam dunia pendidikan sehingga muncul sekolah-sekolah Islam dan Universitas Islam yang kemudian juga memicu munculnya Rumah Sakit Islam, Bank Islam dan lainnya. Kenyataan ini tidak terlepas dari perkembangan Islam Indonesia, terutama usaha yang dilakukan KH. Ahmad Dahlan pada masa pra-kemerdekaan dengan Muhammadiyah yang dibentuknya dalam mendirikan sekolah, rumah sakit, panti asuhan Muhammadiyah yang kemudian memicu pembangunan lembagalembaga masyarakat Islam lainnya.

Kalau dalam periode mistik secara ontologi keislaman adalah idealisme, yakni kenyataan batin dalam wujud kesadaran akan Allah, sedang dalam periode formal adalah realisme, yakni kenyataan obyektif yang sesuai dengan nilai-nilai formal Islam, maka dalam periode ilmiah ontologi keislaman lebih bersifat eksistensialisme. Artinya, keislaman adalah kenyataan eksistensial dari nilai-nilai substansi Islam yang dipahami secara rasional. Dengan demikian, epistemologi dalam nalar ilmiah adalah rasionalitas di mana ajaran Islam dipahami secara rasional dengan menggunakan berbagai pendekatan ilmu yang tidak hanya terbatas pada ilmu agama klasik. Adapun secara aksiologi nalar ilmiah ingin mewujudkan tauhid sebagai kesatuan kemanusiaan dan juga kesatuan kealaman yang terwujud dalam bentuk humanisme-ekologismespiritual. Karenanya keislaman secara aksiologi sesungguhnya adalah manifestasi Islam sebagai rahmatan lil 'alamin yang dapat diterima secara fitrah oleh semua kalangan.

\footnotetext{
Pelajar, 2008)
}

${ }^{42}$ Mujiburrahman, Mengindonesiakan Islam: Representasi dan Ideologi (Yogyakarta: Pustaka 
SKEMA FILOSOFIS NALAR KEISLAMAN URANG BANJAR

\begin{tabular}{|l|l|l|l|}
\hline & Periode Mistik & \multicolumn{1}{|c|}{ Periode Formal } & \multicolumn{1}{|c|}{ Periode Ilmiah } \\
\hline Ontologi & Idealisme & Realisme & Eksistensialisme \\
\hline Epistemologi & Mistik-intuitif & Tekstual-normatif & Rasional \\
\hline Aksiologi & Kesatuan wujud & $\begin{array}{l}\text { Ketaatan pada } \\
\text { norma }\end{array}$ & Rahmatan lil 'alamin \\
\hline
\end{tabular}

\section{Penutup}

Perkembangan nalar keislaman atau nalar keagamaan urang Banjar tidak terlepas dari dialektika antara budaya baru dan budaya lokal (termasuk di dalamnya budaya baru yang bertransformasi menjadi budaya lokal). Hubungan antara keduanya bisa berupa hubungan yang kompromistis seperti antara nalar mitis Hinduisme dan nalar keislaman Mistik, bisa juga hubungan yang bersifat konfrontatif seperti hubungan antara nalar keislaman formal dengan nalar mitis dan nalar mistik.

Untuk kesimpulan filosofis tentang nalar keagamaan dan nalar keislaman urang Banjar tidak akan diuraikan dalam penutup ini karena hal itu bagi penulis sudah cukup tergambar dari dua skema dalam tulisan ini (skema nalar keagamaan pra-Islam dan skema nalar keislaman urang Banjar). Namun yang perlu ditekankan di sini adalah bagaimana dalam setiap perkembangan nalar keagamaan atau nalar keislaman yang ada hanya cerita awal, dan tidak ada cerita akhir. Hal ini dimaksudkan unruk menunjukkan bahwa ketika nalar baru muncul sesungguhnya nalar lama tidak hilang. Oleh karenanya, pada masa kini sesungguhnya dapat diungkapkan bahwa semua nalar mitis, nalar mistik, nalar formal dan nalar limiah masih terus ada pada urang Banjar.

Akhirnya, tulisan ini hanyalah gambaran singkat dari nalar keagamaan yang berkembang pada urang Banjar yang ditulis berdasarkan serpihan-serpihan kisah. Tentunya kita masih memerlukan kajian lebih mendalam mengenai filsafat dan budaya urang Banjar, khususnya nalar kebudayaan urang Banjar sebagai pengayaan khazanah kebudayaan masyarakat Banjar khususnya dan Indonesia umumnya. 


\section{Daftar Pustaka}

Arkoun, Muhammad. Târikbiyyah al-Fiker al-'Arabî al-Islâmî. terj. Hasim Salih. Libanon: Markaz al-Inma’ al-Qoumî, 1986

al-Banjari, Syekh Muhammad Arsyad. "Tuhfatur Ragibin fi Bayani Haqiqati Imani al-Mu'minin wama Yufsidubu Min Riddatil Murtadin". dalam Asywadie Syukur. Pemikiran-Pemikiran Syekh Mubamad Arsyad Al Banjari dalam Bidang Taubid dan Tasawnf. ttp: tp, 2004

Basuni, Ahmad. Nur Islam di Kalimantan Selatan (Sejarab Masuknya Islam di Kalimantan). Surabaya: PT. Bina Ilmu, 1986

Berger, Peter L. dan Thomas Luckmann. Tafsir Sosial atas Kenyataan: Risalah tentang Sosiologi Pengetahuan. Jakarta: LP3ES, 1990

Bleicher, Josef. Contemporary Hermeneutics: Hermeneutics as Method, Philosophy, and Critique. London: Routledge \& Kegan Paul, 1980

Buseri, Kamrani. Paradigma Pendidikan Islam. Disampaikan pada Rapat Senat Terbuka dalam rang pengukuhan Guru Besar IAIN Antasari Banjarmasin, 2005

Chittick, William C. "Rumi dan Wạbdah Al-Wujûd," dalam Kidung Rumi; Puisi dan Mistisisme Dalam Islam. ed. Amin Banani dkk. terj. Joko S. Kahhar. Surabaya: Risalah Gusti, 2001

Dahlan, Bayani dkk. Studi Naskah Kitab Barencong Datu Sanggul. Banjarmasin: Pusat Penelitian IAIN Antasari Banjarmasin, 2007

Daud, Alfani. Islam dan Masyarakat Banjar: Deskripsi dan Analisa Kebudayaan Banjar. Jakarta: Rajawali Press, 1997

Foucault, Michel. The Archeology of Knowledge. terj. A. M. Sheridan Smith. London: Tavistock Publications, 1974

Harb, 'Alî. Kritik Nalar Al-Qur'an. terj. M. Faisal Fatowi. Yogyakarta: LKIS, 2003 
Ideham , M, Suriansyah dkk (ed.). Sejarah Banjar, cet. ke-3. Banjarmasin: Badan Penelitian dan Pengembangan Daerah Propinsi Kalimantan Selatan, 2007

-------, Urang Banjar dan Kebudayaannya. cet. ke-2. Banjarmasin: Badan Penelitian dan Pengembangan Daerah Propinsi Kalimantan Selatan, 2007

al-Jâbirî, Muhammad 'Âbid. Takwin al-'Aql al-'Arabî. Beirut: Markaz Dirâsât alWihdah al-'Arabiyyah, 1989

------, Bunyah al-'Aql al-'Arabî. Beirut: Markaz Dirâsât al-Wihhdah al'Arabiyyah, 1990

Khun, Thomas S. The Structure of Scientific Revolution. Herndon: The University of Chicago Press, 1970

Mujiburrahman. Mengindonesiakan Islam: Representasi dan Ideologi. Yogyakarta: Pustaka Pelajar, 2008

Noer, Kautsar Azhari. Ibn al-'Arabî; Wablah al-Wujûd dalam Perdebatan. Jakarta: Paramadina, 1995

Syafruddin dan Syahriansyah. Ajaran Tasawnf Syekh Hamid Abulung. Yogyakarta: Sumbangsih Press, 2007 